\title{
Испытательная лаборатория НПК "Суперметалл": быстро, надежно и достоверно
}

О.Е.Пухова К.Х.Н., Т.Ф.Васекина К.Х.Н., Н.В. Ровинская, И. В. Борягина АО «НПК "Суперметалл", Москва pukhova.o@yandex.ru
УДК 543.07

Статья получена 07.10.2019

Принята к публикации 30.10.2019

\begin{abstract}
В статье представлена деятельность испытательной лаборатории АО «НПК «Суперметалл» (ИЛ), рассмотрены методы анализа, применяемые для определения состава платиновых металлов, их сплавов и примесных элементов при переработке вторичного сырья драгоценных металлов и изготовлении изделий технического назначения из них. Дано краткое описание используемых методик измерений и приведены их метрологические характеристики. Предложена унифицированная методика определения примесей, учитывающая влияние матричных эффектов. Лаборатория аккредитована и принимает участие в аттестации стандартных образцов состава и межлабораторных сличительных испытаниях.
\end{abstract}

Металлы платиновой группы (МПГ) находят широкое применение в различных отраслях промышленности благодаря своим уникальным свойствам. Высокие температуры плавления, сопротивление коррозии и разрушению делают эти металлы и их сплавы незаменимыми для изготовления оборудования по производству высококачественных стекол, стеклянных волокон и монокристаллов оксидных соединений. Несмотря на постоянный рост цен на МПГ, их потребление неуклонно растет. Научно-производственный комплекс "Суперметалл" им. Е. И. Рытвина более 55 лет занимается переработкой сырья драгоценных металлов, производством материалов, изделий и оборудования на основе платиновых сплавов, например, стеклоплавильных аппаратов, каталитических систем, специального лабораторного оборудования, изделий медицинского назначения [1]. Основную долю сырья для производства новой продукции составляют лом и отходы изделий из платиновых металлов, что существенно сокращает расход драгоценных металлов и способствует уменьшению безвозвратных потерь. Испытательная лаборатория (Ил) АО «НПК "Суперметалл" анализирует поступающее сырье на всех стадиях его переработки и при изготовлении новых изделий технического назначения из переработанных платиновых металлов.

Испытательная лаборатория аккредитована в международном органе по аккредитации ААЦ "Аналитика" и выполняет все требования и рекомендации ГОСТ-17025 «Общие требования к компетентности испытательной лаборатории". Лаборатория обеспечивает оперативный и достоверный контроль химического состава драгоценных металлов и их сплавов, содержания основных, легирующих и примесных элементов на всех этапах производства, подтверждая свою компетентность успешным прохождением межлабораторных сличительных испытаний [2]. Лаборатория располагает современными отечественными и зарубежными средствами измерения, испытательным оборудованием, стандартными образцами для проведения всех необходимых испытаний, научно-исследовательских работ по совершенствованию анализа благородных металлов и разработки новых технологических и производственных процессов и решений. Сотрудники имеют высокую квалификациюна базе специального образования и большой опыт работы с объектами из драгоценных металлов.

Неотъемлемой частью контроля поступающих на переработку сырья и материалов является отбор представительных проб, состав которых характеризует весь объект. Этот процесс реализуется с помощью разработанных в лаборатории стандартов организации отбора образцов (СТП). Погрешность (неопределенность) пробоотбора пренебрежимо мала по сравнению с метрологическими характеристиками аттестованных методик.

Контроль металлов и сплавов на содержание примесей осуществляется атомно-эмиссионным и атомноабсорбционными методами анализа с использованием ГСО и собственных аттестованных методик, не уступающих 
Таблица 1. Диапазоны измерений Al, Ag, As, Au, Bi, Ca, Cd, Cr, Cu, Fe, Ir, Mg, Mn, Mo, Ni, Pb, Pd, Ru, Sb, Si, Sn, u Zn и метрологические показатели методики «Определение массовых долей примесей в пробах платинородиевых сплавов методом атомно-эмиссионной спектроскопии» [4], отн. \%

\begin{tabular}{|l|c|c|c|c|}
\hline $\begin{array}{l}\text { Диапазон } \\
\text { измерений, } \\
\text { массовая доля }\end{array}$ & $\begin{array}{c}\text { Показатель } \\
\text { повторяемости, } \\
\sigma_{r}, \text { отн }\end{array}$ & $\begin{array}{c}\text { Показатель внутрилабора- } \\
\text { торной прецизионности } \\
\sigma_{R, л} \text { отн }\end{array}$ & $\begin{array}{c}\text { Показатель } \\
\text { точности } \pm \delta_{л}, \\
(P=0,95)\end{array}$ & $\begin{array}{c}\text { Расширенная неопреде- } \\
\text { ленность измерения } \pm U_{\text {л, }} \\
(\mathrm{P}=0,95)\end{array}$ \\
\hline От 0,0003 до 0,05 & 12 & 17 & 35 & 37 \\
\hline От 0,05 до 0,35 вкл. & 7 & 7 & 15 & 17 \\
\hline
\end{tabular}

по метрологическим характеристикам существующим стандартным методикам, а по количеству определяемых примесных элементов иногда и превосходящих их. Для этих целей лаборатория оснащена соответствующими спектральными приборами. Для атомно-эмиссионного анализа используются атомно-эмиссионный (АЭС) спектрометр СПАС-01 с дуговым возбуждением спектра и спектрограф ДФС-8 с многоканальным анализатором спектра отечественного производства. Для возбуждения спектров применяется генератор дуги постоянного или переменного тока с силой до 15 А. Атомно-абсорбционный анализ проводится на атомно-абсорбционном (AАA) спектрометре «novAA-330" с пламенным атомизатором (производство Analytik Jena, Германия). Прибор укомплектован набором необходимых ламп с полым катодом.

Для анализа атомно-эмиссионным методом с дуговым возбуждением спектра платинородиевых сплавов, не соответствующих имеющимся ГСО, в испытательной лаборатории разработана унифицированная методика определения примесей. Она учитывает влияние матричных эффектов, а также различие между стандартными образцами, используемыми для построения градуировочных характеристик, и реальными пробами. В результате проведенных исследований $[3,4]$ по определению примесей в приготовленных смесях по градуировочным графикам, построенным по стандартным образцам, были определены диапазоны, в которых содержание родия не влияет на определение примесей. Так, сплавы с содержанием родия от 0,1 до 5\% масс. включительно анализируются по градуировочным графикам, построенным по стандартным образцам Пл, от 5 до 15\% масс. - по градуировочным графикам, построенным по стандартным образцам ПлРд90-10, и от 15 до 35\% масс. - по градуировочным графикам, построенным по стандартным образцам ПлРд8020 [5]. Таким образом, условия анализа сплавов, составы которых находятся в выбранных диапазонах, оказываются близки к тем, при которых строятся градуировочные характеристики с использованием стандартных образцов. Метрологические характеристики унифицированной методики представлены в табл. 1.
Контроль примесных элементов, содержание которых выходит за пределы диапазона определения по атомно-эмиссионным методикам, проводится атомноабсорбционным методом с пламенной атомизацией пробы $[6,7]$. Массовая концентрация элементов определяется по градуировочным графикам или по методу ограничивающих растворов, комбинированному с методом добавок, который заключается в установлении содержания определяемого элемента в исследуемой пробе по

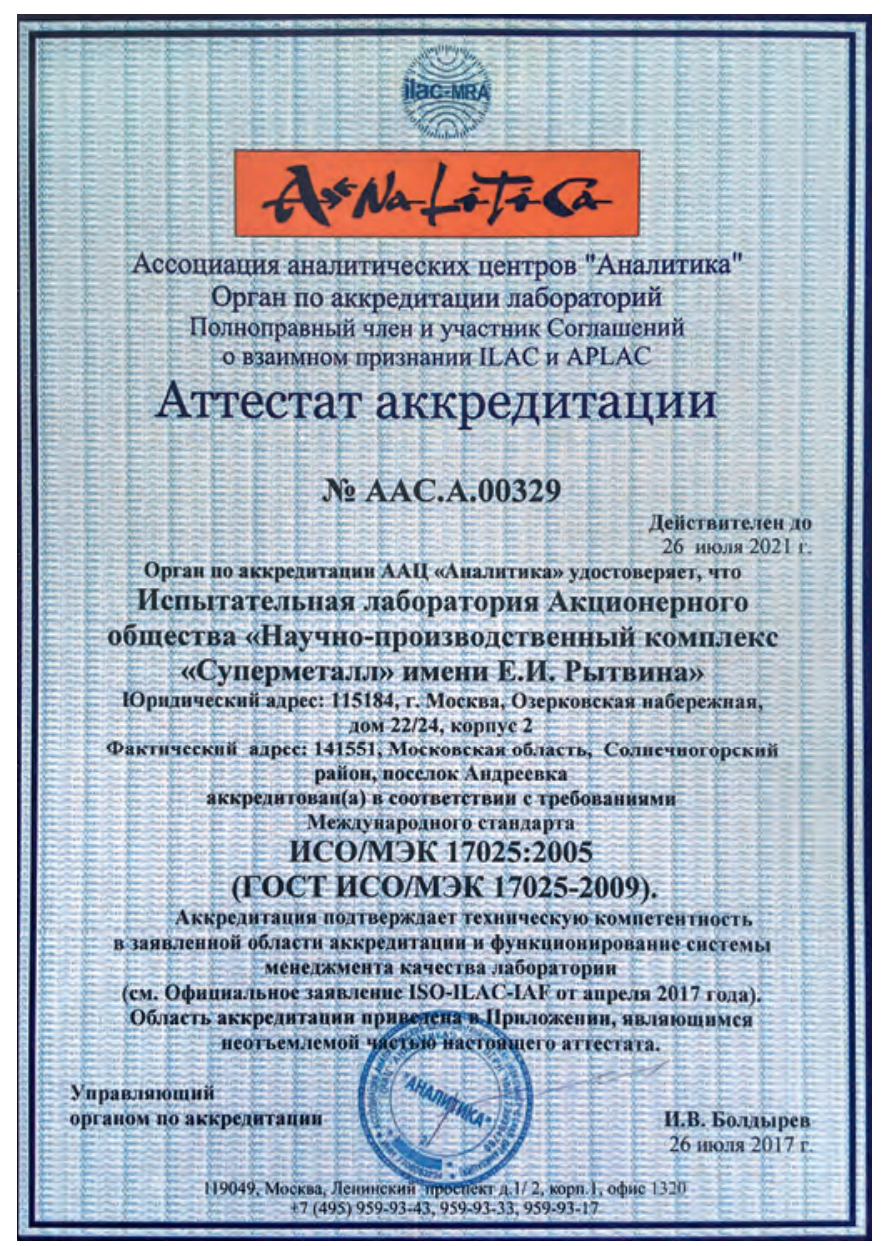

Ammecmam аккредитации 


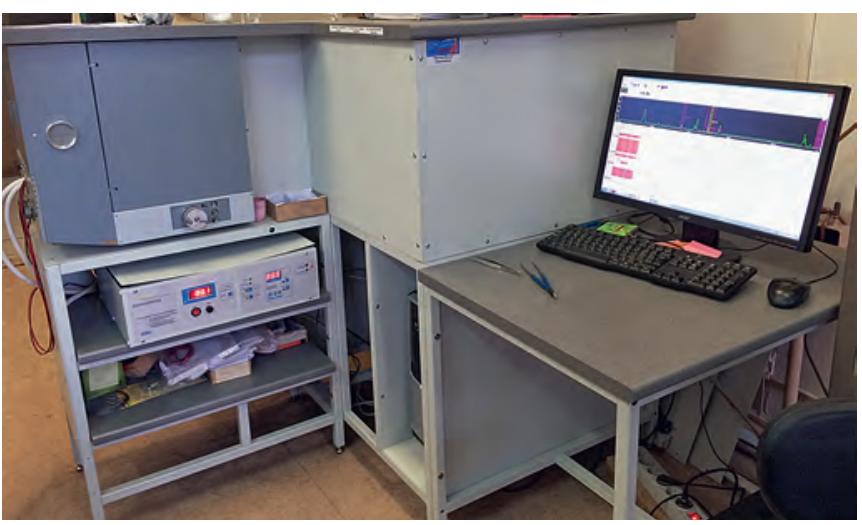

Атомно-эмиссионный спектрометр СПАС-01 с дуговым возбуждением спектра линейной зависимости абсорбции растворов с добавками меньшего и большего фиксированного количества определяемого компонента. Этот метод применяется также при возможном нарушении стабильности измерений и для анализа сплавов сложного или нестандартного состава.

Вскрытие проб проводится в смеси концентрированных азотной и соляной кислот (1:3) ("царская водка") при нагревании. Для сокращения времени испытаний и максимального перевода анализируемых элементов в раствор при анализе керамических материалов и сплавов с содержанием родия более 20\% масс. вскрытие пробы проводится в аналитических автоклавах. После растворения образцов отгоняются оксиды азота с помощью концентрированной соляной кислоты. Все испытания проводятся

Таблица 2. Диапазоны измерений и метрологические показатели методик измерений массовых долей неблагородных металпов, серебра, золота, родия, паляадия и платины в платиноидах и их сплавах атомно-абсорбционным методом, отн. \%

\begin{tabular}{|c|c|c|c|c|}
\hline $\begin{array}{l}\text { Диапазон измерений, } \\
\text { массовая доля }\end{array}$ & $\begin{array}{c}\text { Показатель } \\
\text { повторяемости, } \\
\sigma_{r}, \text { отн }\end{array}$ & $\begin{array}{c}\text { Показатель внутрилабо- } \\
\text { раторной прецизионно- } \\
\text { сти } \sigma_{\mathrm{R}, \text { л }} \text { отн }\end{array}$ & $\begin{array}{c}\text { Показатель } \\
\text { точности } \pm \delta_{\wedge} \\
(P=0,95)\end{array}$ & $\begin{array}{c}\text { Расширенная неопреде- } \\
\text { ленность измерения } \pm \mathrm{U}_{\text {л, }} \\
(\mathrm{P}=0,95)\end{array}$ \\
\hline \multicolumn{5}{|c|}{$\begin{array}{l}\text { Методика измерений массовых долей неблагородных металлов, серебра и золота в платиноидах } \\
\text { и их сплавах атомно-абсорбционным методом [6] }\end{array}$} \\
\hline \multicolumn{5}{|l|}{$\mathrm{Ag}$} \\
\hline От 0,01 до 0,5 вкл. & 3,5 & 4,0 & 8,0 & 8,0 \\
\hline Св. 0,5 до 6,0 вкл. & 2,0 & 2,5 & 5,0 & 5,0 \\
\hline \multicolumn{5}{|l|}{$\mathrm{Au}$} \\
\hline От 0,01 до 0,5 вкл. & 3,0 & 3,5 & 7,0 & 8,0 \\
\hline Св. 0,5 до 6,0 вкл. & 2,0 & 2,5 & 5,0 & 5,0 \\
\hline \multicolumn{5}{|c|}{$\mathrm{Cr}, \mathrm{Cu}, \mathrm{Fe}, \mathrm{Mn}, \mathrm{Ni}, \mathrm{Zn}, \mathrm{Pb}^{1}$ и $\mathrm{Sn}^{2}$} \\
\hline От 0,01 до 0,5 вкл. & 3,0 & 3,0 & 6,0 & 8,0 \\
\hline Св. 0,5 до 6,0 вкл. & 2,0 & 2,5 & 5,0 & 5,0 \\
\hline \multicolumn{5}{|c|}{$\begin{array}{l}\text { Методика измерений массовых долей родия, палладия и платины в платиноидах } \\
\text { и их сплавах атомно-абсорбционным методом [7] }\end{array}$} \\
\hline \multicolumn{5}{|l|}{ Pt } \\
\hline От 0,1 до 0,5 вкл. & 4,0 & 4,0 & 8,0 & 8,6 \\
\hline Св. 0,5 до 10,0 вкл. & 3,0 & 3,5 & 7,0 & 7,2 \\
\hline \multicolumn{5}{|l|}{$\mathrm{Pd}, \mathrm{Rh}$} \\
\hline От 0,01 до 0,5 вкл. & 4,5 & 4,5 & 9,0 & 9,6 \\
\hline Св. 0,5 до 10,0 вкл. & 3,0 & 3,0 & 6,0 & 7,0 \\
\hline
\end{tabular}

1 Нижняя граница диапазона методики по свинцу 0,05\%.

2 Нижняя граница диапазона методики по олову 0,1\%. 
Таблица 3. Диапазоны измерений и метрологические методики измерений массовых долей платины, родия и паляадия в шамотно-керамических материалах атомно-абсорбционным методом [8], отн. \%

\begin{tabular}{|c|c|c|c|c|}
\hline $\begin{array}{l}\text { Диапазон измерений, } \\
\text { массовая доля }\end{array}$ & $\begin{array}{c}\text { Показатель } \\
\text { повторяемости, } \\
\sigma_{r}, \text { отн }\end{array}$ & $\begin{array}{c}\text { Показатель внутрила- } \\
\text { бораторной прецизион- } \\
\text { ности, } \sigma_{R, ~ л} \text { отн }\end{array}$ & $\begin{array}{l}\text { Показатель } \\
\text { точности, } \pm \delta_{\pi} \\
(P=0,95)\end{array}$ & $\begin{array}{c}\text { Расширенная неопреде- } \\
\text { ленность измерения, } \\
\pm U_{\pi, m}(P=0,95)\end{array}$ \\
\hline \multicolumn{5}{|l|}{ Pt } \\
\hline От 0,01 до 0,1 вкл. & 9,0 & 10,0 & 21,0 & 22,0 \\
\hline Св. 0,1 до 3 вкл. & 5,0 & 5,0 & 10,0 & 11,0 \\
\hline \multicolumn{5}{|l|}{$\mathrm{Rh}$} \\
\hline От 0,001 до 0,005 вкл. & 13,0 & 15,0 & 31,0 & 33,0 \\
\hline Св. 0,005 до 0,05 вкл. & 9,0 & 10,0 & 21,0 & 22,0 \\
\hline Св. 0,05 до 0,3 вкл. & 5,0 & 5,0 & 10,0 & 11,0 \\
\hline \multicolumn{5}{|l|}{$\mathrm{Pd}$} \\
\hline От 0,0005 до 0,005 вкл. & 13,0 & 15,0 & 31,0 & 32,0 \\
\hline Св. 0,005 до 0,15 вкл. & 9,0 & 10,0 & 21,0 & 22,0 \\
\hline
\end{tabular}

с использованием государственных стандартных образцов утвержденного типа с установленными метрологическими характеристиками.

Платиновые металлы не мешают определению неблагородных элементов, поэтому влияние матричного раствора (раствора платиноидов) учитывается только при анализе металлов платиновой группы. Метрологические характеристики разработанных методик $[6,7]$ представлены в табл. 2.

В процессе эксплуатации стеклоплавильных аппаратов часть платиновых металлов переходит шамотнокерамическую футеровку устройств. В целях рационального использования металлов платиновой группы эти металлы максимально извлекаются из отработанных

Таблица 4. Метрологические показатели методик измерения массовых долей Pd [10] и Pt [9], абс. \%

\begin{tabular}{|c|c|c|c|c|}
\hline $\begin{array}{l}\text { Массовая } \\
\text { доля }\end{array}$ & $\begin{array}{c}\text { Показатель повторяемо- } \\
\text { сти, } \sigma_{r}\end{array}$ & $\begin{array}{c}\text { Показатель внутрилабо- } \\
\text { раторной прецизионно- } \\
\text { сти, } \sigma_{R, ~ л}\end{array}$ & $\begin{array}{c}\text { Границы интервала аб- } \\
\text { солютной погрешности, } \\
\pm \Delta_{\text {л }}(\mathrm{P}=0,95)\end{array}$ & $\begin{array}{c}\text { Расширенная не- } \\
\text { определенность } \\
\text { измерения } \\
\pm U_{\pi, \mathrm{m}}(\mathrm{P}=0,95)\end{array}$ \\
\hline \multicolumn{5}{|c|}{$\begin{array}{l}\text { Методика измерений массовой доли палладия в сплавах платиноидов гравиметрическим и атомно-абсорбционным } \\
\text { методами (Pd) [10] }\end{array}$} \\
\hline 10,00 & 0,05 & 0,02 & 0,13 & 0,13 \\
\hline 25,00 & 0,12 & 0,05 & 0,31 & 0,31 \\
\hline 50,00 & 0,20 & 0,06 & 0,60 & 0,62 \\
\hline 62,50 & 0,29 & 0,07 & 0,81 & 0,82 \\
\hline 90,00 & 0,33 & 0,09 & 1,04 & 1,06 \\
\hline \multicolumn{5}{|c|}{$\begin{array}{l}\text { Определение массовой доли платины в сплавах платиноидов гравиметрическим методом, комбинированным } \\
\text { с методом атомной абсорбции (Pt) [9] }\end{array}$} \\
\hline 20,00 & 0,09 & 0,06 & 0,26 & 0,29 \\
\hline 35,00 & 0,13 & 0,07 & 0,43 & 0,43 \\
\hline 50,00 & 0,18 & 0,09 & 0,60 & 0,61 \\
\hline 65,00 & 0,21 & 0,11 & 0,78 & 0,79 \\
\hline
\end{tabular}


Таблица 5. Диапазоны измерений и метрологические показатели методик измерений массовых долей компонентов в платиноидах и их сплавах методами рентгеноспектрапьного флуоресцентного анализа [12, 13], абс. \%

\begin{tabular}{|c|c|c|c|c|}
\hline $\begin{array}{l}\text { Диапазон измерений, } \\
\text { массовая доля }\end{array}$ & $\begin{array}{c}\text { Показатель } \\
\text { повторяемости, } \sigma_{\mathrm{r}}\end{array}$ & $\begin{array}{c}\text { Показатель внутрила- } \\
\text { бораторной прецизи- } \\
\text { онности, } \sigma_{R, ~}\end{array}$ & $\begin{array}{c}\text { Показатель точности } \\
(\mathrm{P}=0,95), \pm \Delta_{\mathrm{I}}\end{array}$ & $\begin{array}{c}\text { Расширенная не- } \\
\text { определенность } \\
\text { измерения } \\
\pm U_{\text {л, m }}(P=0,95)\end{array}$ \\
\hline \multicolumn{5}{|c|}{$\begin{array}{l}\text { Методика измерений массовых долей родия, циркония, железа в платинородиевых сплавах } \\
\text { методом рентгеноспектрального флуоресцентного анализа [12] }\end{array}$} \\
\hline \multicolumn{5}{|l|}{ Родий } \\
\hline От 0,1 до 5,0 вкл. & $0,0073+0,0139 x$ & $0,0068+0,105 x$ & $0,0126+0,0298 x$ & $0,0129+0,03 x$ \\
\hline Св. 5,0 до 40,0 вкл. & 0,080 & $0,0749+0,0015 x$ & $0,1649+0,0041 x$ & $0,1683+0,0042 x$ \\
\hline \multicolumn{5}{|l|}{ Цирконий } \\
\hline От 0,08 до 0,27 вкл. & 0,0060 & 0,0065 & 0,028 & 0,031 \\
\hline \multicolumn{5}{|l|}{ Железо } \\
\hline От 0,18 до 4,0 вкл. & $0,0057+0,0042 x$ & $0,0108+0,0144 x$ & $0,0438+0,0189 x$ & $0,0447+0,0193 x$ \\
\hline \multicolumn{5}{|c|}{$\begin{array}{l}\text { Методика измерений массовой доли платины, родия, палладия и никеля в платиноидах } \\
\text { и их сплавах рентгеноспектральным флуоресцентным методом [13] }\end{array}$} \\
\hline \multicolumn{5}{|c|}{ Палладий-никелевые (PdNi) Ni: } \\
\hline От 3,0 до 6,0 вкл. & 0,5 & 0,7 & $0,02 x$ & $0,021 x$ \\
\hline \multicolumn{5}{|c|}{ Палладий-платина-родиевые (PdPtRh), Pt } \\
\hline От 0,5 до 5,0 вкл. & 1,5 & 1,8 & $0,04 x$ & $0,041 x$ \\
\hline \multicolumn{5}{|c|}{ Платина-родий-палладиевые (PtRhPd), Pd } \\
\hline От 0,5 до 5,0 вкл. & 0,9 & 1,1 & $0,026 x$ & $0,027 x$ \\
\hline Св. 5,0 до 50 вкл. & 0,5 & 0,5 & $0,011 x$ & $0,012 x$ \\
\hline \multicolumn{5}{|c|}{ Платина-родиевые (PtRh), Rh } \\
\hline От 3,0 до 6,0 вкл. & 1,4 & 1,4 & $0,03 x$ & $0,031 x$ \\
\hline Св. 6,0 до 20,0 вкл. & 1,0 & 1,0 & $0,023 x$ & $0,024 x$ \\
\hline Св. 20,0 до 40,0 вкл. & 0,4 & 0,5 & $0,014 x$ & $0,015 x$ \\
\hline
\end{tabular}

Примечание: х-результат анализа.

шамотно-керамических материалов. Для достоверной оценки содержания МПГ в шамотно-керамических материалах в Ил разработана и внедрена методика измерения массовой доли платины в диапазоне от 0,01 до 3\% масс., родия в диапазоне от 0,001 до 0,3\% масс. и палладия в диапазоне от 0,0005 до 0,15\% масс. [8], а также установлены правила отбора образцов и их пробоподготовки. Метрологические показатели представлены в табл. 3.

При содержании платины от 20 до 90\% масс. и палладия от 10 до 90\% масс. в испытательной лаборатории применяются гравиметрические методы, комбинированные с атомной абсорбцией. Платина осаждается в виде гексахлоплатината аммония, который подвергается прокаливанию [9]. Получившаяся после прокаливания платиновая губка растворяется в смеси концентрированных кислот и в полученном растворе атомно-абсорбционным методом определяется содержание соосадившихся вместе с ней палладия и родия. Атомно-абсорбционным методом также определяется содержание платины, оставшееся в фильтратах. Палладий осаждается в виде диметилглиоксимина, который является весовой формой. Содержание неосадившегося палладия в фильтратах определяется атомно-абсорбционным методом [10, 11]. Разработанные методы позволяют значительно сократить время выполнения анализа без потери точности определения макрокомпонентов. Метрологические показатели методик представлены в табл. 4.

Определение основных компонентов в ПлРдсплавах проводится с помощью рентгеноспектрального 


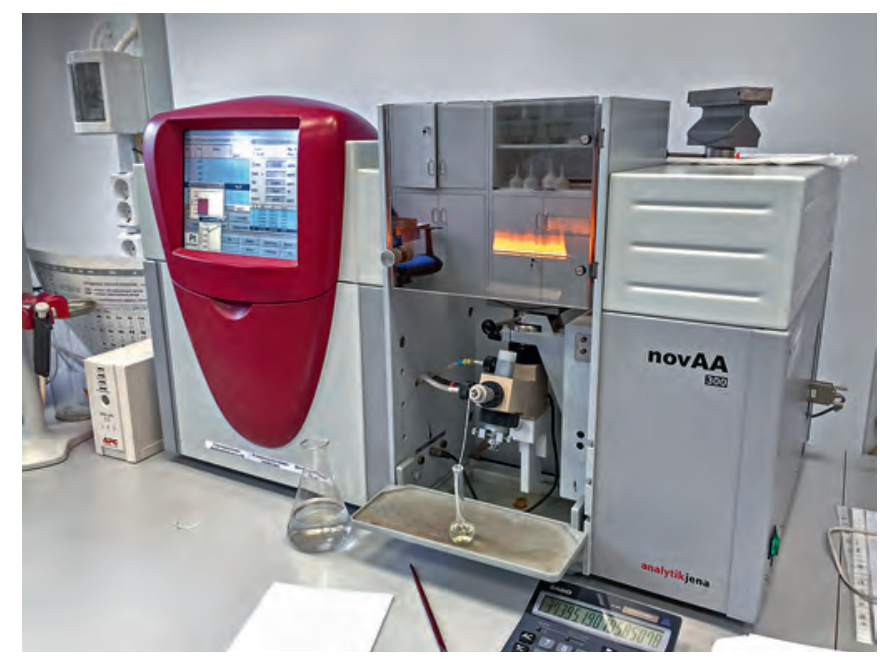

Атомно-абсорбционный спектрометр поуАА-330 с пламенным атомизатором

флуоресцентного анализа (РФА) на энергодисперсионном спектрометре "Спектроскан "МАКС-G" (производство ООО "НПО "Спектрон", Санкт-Петербург) [12, 13]. Сканирующий кристалл-дифракционный канал позволяет измерять интенсивность излучения определенной длины волны (энергии). Рабочий диапазон длин волн сканирующего канала обеспечивает измерение интенсивностей спектральных линий химических элементов в диапазоне от кальция (20 Ca) до урана (92 U) от 0,01 до 100\% масс. Метод позволяет быстро и без потерь платиновых металлов определить состав анализируемых сплавов.

В методе внешнего стандарта концентрация элемента в пробе рассчитывается прямым сопоставлением интенсивностей аналитических линий, зарегистрированных от пробы и образца сравнения, или с предварительным построением градуировочных графиков. В качестве образцов сравнения используются аттестованные стандартные образцы (ГСО), которые по составу соответствуют большинству анализируемых сплавов ПлРд. Количественный анализ образцов неизвестного или сложного состава можно проводить с помощью программы метода фундаментальных параметров без стандартных образцов сравнения или с использованием всего одного стандартного образца для каждого типа анализируемого сплава. В качестве стандартного образца в данном случае используются пробы с установленным другими способами составом или специально полученный материал нужного состава. Метрологические показатели методик представлены в табл. 5.

Для определения золота от 33,0 до 99,5\% масс. в лаборатории реализован метод купелирования [14], на основании которого в 2018 году испытательная лаборатория принимала участие в аттестации стандартного образца состава 99,5\% масс. золота.

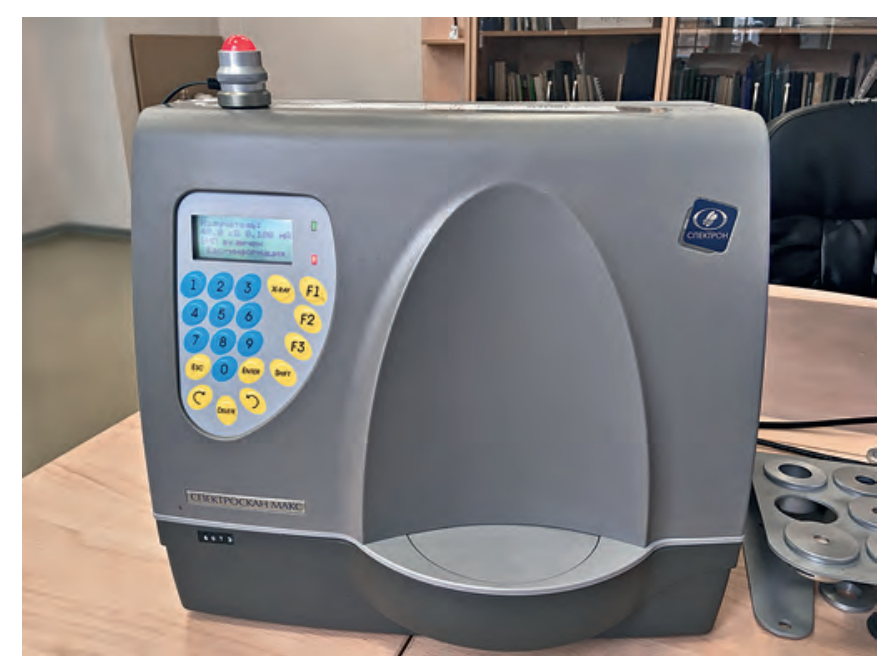

Энергодисперсионный спектрометр «Спектроскан МАКС-G»

В лаборатории разработаны спектрофотометрические методы для определения окисленной и неокисленной форм циркония в платине и платинородиевых сплавах, родия в платинородиевых сплавах, платины и палладия в тройных сплавах ПлРдПд.

Сотрудники испытательной лаборатории стремятся к увеличению точности и скорости анализа драгоценных металлов, разрабатывают новые или улучшают старые методы анализа, исследуют различные нестандартные продукты, проводят работы по метрологическому обеспечению качества аналитических процессов. Испытательная лаборатория AO “НПК "Суперметалл" В своей деятельности ориентируется на потребности производства и решение задач аналитического сопровождения разработок новых технологических процессов и новых материалов.

\section{ЛИТЕРАТУРА:}

1. Васекин В. В., Морозова Л.э., Ястребов В.А. Достижения ОАО "НПК" Суперметалл" в области разработки и производства продукции из драгоценных металлов // Цветные металлы. 2012. № 5. С. 31-36.

2. Ровинская Н.В., Лузан С. В. Аналитическая лаборатория ОАО «НПК» Суперметалл" // Цветные металлы. 2012. № 5. С. 36-39.

3. МВИ СМ-004-2015. Методика измерений массовых долей примесей в платине, платинородиевых сплавах и палладии методом атомноэмиссионной спектроскопии, - М., 2015. 14 с.

4. МВИ СМ-010-2017. Определение массовых долей примесей в пробах платинородиевых сплавов методом атомно-эмиссионной спектроскопии. - М., 2015. 12 с.

5. Пухова О.Е., Васекина Т.Ф. Унифицированная методика определения массовых долей примесей в платинородиевых сплавах методом атомно-эмиссионной спектроскопии // Заводская лаборатория. Диагностика материалов. 2018. Т. 84. № 4. С. 22-26.

6. МВИ СМ-001-2015. Определение массовых долей неблагородных металлов, серебра и золота в платиноидах и их сплавах атомноабсорбционным методом. - М., 2015. 23 с.

7. МВИ СМ-007-2015. Определение массовых долей родия, палладия и платины в платиноидах и их сплавах атомно-абсорбционным методом. - М., 2015. 23 с. 
8. МВИ СМ-009-2015. Методика измерений массовых долей платины, родия и палладия в шамотно-керамических материалах атомноабсорбционных методом. - М., 2015. 15 с.

9. МВИ СМ-003-2015. Определение массовой доли платины в сплавах платиноидов гравиметрическим методом, комбинированным с методом атомной абсорбции. - М., 2015. 21 с.

10. МВИ СМ-002-2015. Методика измерений массовой доли палладия в сплавах платиноидов гравиметрическим и атомноабсорбционным методами. - М., 2015. 18 с.

11. Васекина Т.Ф., Борягина И.В., Пятахина Е.С., Ровинская Н.В. Особенности гравиметрического определения палладия в палладийсодержащих объектах // Заводская лаборатория. Диагностика материалов. 2013, Т. 79. № 1. С. 15-18.

12. МВИ СМ-005-2015. Методика измерений массовых долей родия, циркония, железа в платинородиевых сплавах методом рентгеноспектрального флуоресцентного анализа. - М., 2015. 14 с.

13. СМ-008-2015. Методика измерений массовой доли платины, родия, палладия и никеля в платиноидах и их сплавах рентгеноспектральным флуоресцентным методом. - М., 2015. 14 с.

14. ISO 11426:2014. Ювелирное дело. Определение содержания золота в золотых ювелирных сплавах. Метод купелирования (пробирный анализ). - М., 2014. 14 с

\section{REFERENCES}

1. Vasekin V.V., Morozova L. E., Yastrebov V. A. Achievements of JSC Supermetal in the field of development and production of precious metal products. Cvetnye metally - Non-ferrous Metals, 2012, no. 5, pp. 31-36.

2. Rovinskaya N.V., Luzan S. V. Analytical Laboratory of JSC Supermetal Cvetnye metally - Non-ferrous Metals, 2012, no. 5, pp. 36-39.

3. MVI SM-004-2015. The method of measurement of mass fraction of impurities in the platinum, rhodium and palladium alloys by atomic emission spectroscopy. M., 2015, 13 p.
4. MVI SM-010-2017. Determination of mass fractions of impurities in samples of platinum-rhodium alloys by atomic emission spectroscopy. M., 2017, 12 p.

5. Pukhova O.E., Vasekina T.F. A unified technique of determining mass fractions of the impurities in platinum-rhodium alloys by atomic emission spectroscopy (AES). Industrial laboratory. Diagnostics of materials. 2018, 84(4), pp. 22-26 (In Russ).

6. MVI SM-001-2015. Determination of the mass fractions of base metals, silver and gold in platinoids and their alloys by the atomic absorption method. M., 2015, 23 p.

7. MVI SM-007-2015. Determination of the mass fractions of rhodium, palladium and platinum in platinoids and their alloys by the atomic absorption method. M., 2015, 23 p.

8. MVISM-009-2015. Methodology for measuring the mass fractions of platinum, rhodium and palladium in chamotte-ceramic materials by the atomic absorption method. M., 2015, $15 \mathrm{p}$.

9. MVISM-003-2015. Determination of the mass fraction of platinum in platinum alloys by the gravimetric method combined with the atomic absorption method. M., 2015, $21 \mathrm{p}$.

10. MVISM-002-2015. Methodology for measuring the mass fraction of palladium in platinum alloys by gravimetric and atomic absorption methods. M., 2015, $18 \mathrm{p}$.

11. Vasekina T.F., Boryagina I.V., Pyatakhina E. S., Rovinskaya N. V. Features of Gravimetric Determination of Palladium in Palladium-Containing Compounds. Industrial laboratory. Diagnostics of materials. 2013, 79 (1), pp. 15-18 (In Russ).

12. MVISM-005-2015. Methodology for measuring the mass fractions of rhodium zirconium, iron in platinum rhodium alloys by $\mathrm{X}$-ray fluorescence analysis. M., 2015, 14 p.

13. SM-008-2015. Method for measuring the mass fraction of platinum, rhodium, palladium and nickel in platinum and their alloys by the X-ray fluorescence method. M., 2015, 14 p.

14. ISO 11426:2014. Jewellery - Determination of gold in gold jewellery alloys Cupellation method (fire assay). M., 2014, 14 p.

\section{(ब() ИЗДАТЕЛЬСТВО «ТЕХНОСФЕРА» ПРЕДСТАВЛЯЕТ КНИГУ:}

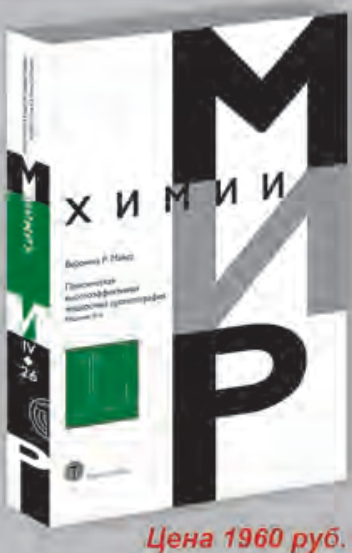

Цена 1960 руб.
Майер Вероника P.

Практическая высокоэффективная жидкостная хроматография. Издание 5-е.

M.: TEXHOCФEPA, 2019, - 408 c., ISBN 978-5-94836-480-3

Представляем читателю 5-е издание книги, которое расширено за счет современных методов и оборудования. В книге многое доработано, добавлено большое количество ссылок Те места в тексте, где не хватало информации о современном положении дел в ВЭЖХ или нужны были дополнительные разъяснения, снабжены примечаниями переводчиков, также добавлены ссылки на соответствующую литературу. В издание включена новая тема контроль качества. Два раздела в приложениях были обновлены и расширены Бруно И. Ленди - раздел о тестировании хроматографической системы и раздел о выявлении и устранении неисправностей. Были написаны некоторые новые разделы. Книга отличается простотой изложения и, что не менее важно, такими же простыми и понятными иллюстрациями, значительно облегчающими понимание излагаемого материала. Несомненное достоинство книги - множество практических задач, которые автор предлагает решить начинающему хроматографисту в ходе обучения. Издание рекомендовано начинающим изучать высокоэффективную жидкостную хроматографию (ВЭЖХ).

КАК ЗАКАЗАТЬ НАШИ КНИГИ?

125319, Москөа, a/я 91; тел + +7 495 234-0110; факс: +7 495 956-3346; e-mail: knigi@technosphera.ru; sales@technosphera.ru 


\section{Московский международный}

Салон изобретений

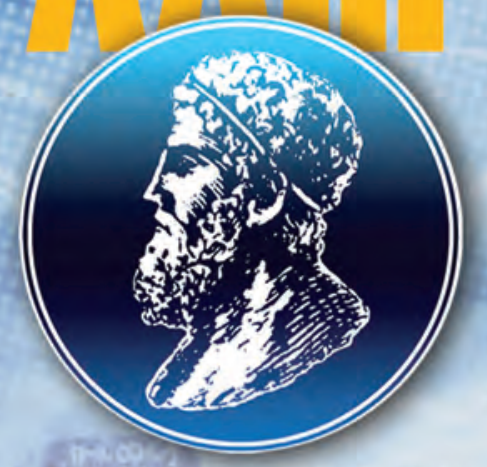

\section{и инновационных технологий}

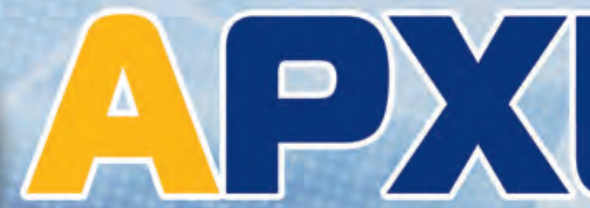

24 - 27 mapraz-20 20

Москва, Россия, Конгрессно-выставочный центр "Сокольимкй", пйвильон №2

Конкурсная программа

Презентация высокотехнологичных проектов 58. 21] Международная выставка товарных s - दाзод знаков «Товарный знак - Лидер»

Международная научно-практическая конференция «Актуальные вопросы изобретательской,

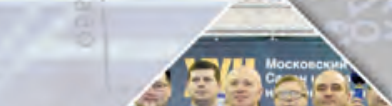

и патентно-лицензионной деятельности»

у 7 . Международная выставка изобретений,
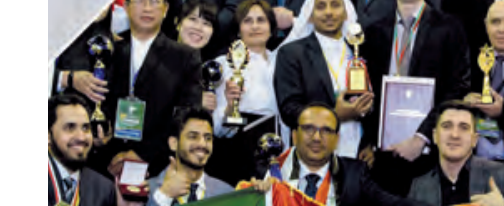

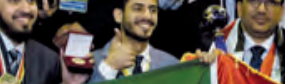

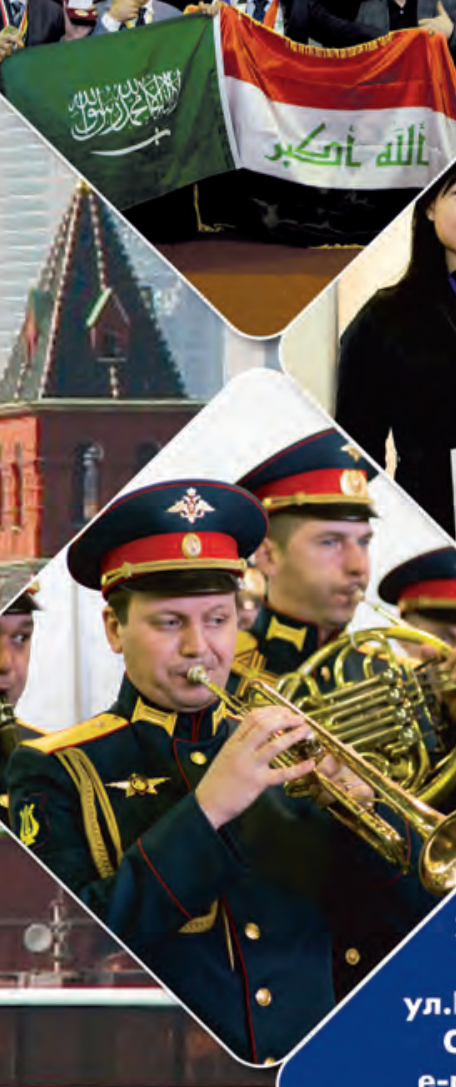

\section{новых продуктов и услуг}

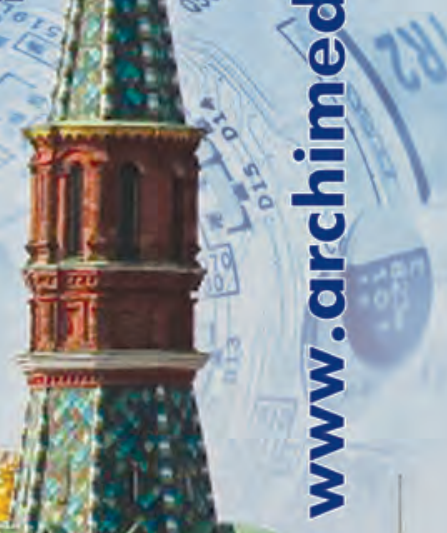

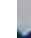
Телефон e-mail: mail@archimedes.ru and 